\title{
ORTADOĞU ÜLKELERİNDE SUÇ ORANLARINA GENEL BİR BAKIŞ ${ }^{*}$
}

\author{
An Overview of Crime Rates in the Middle East Countries
}

\section{Zahir KIZMAZ*}

\begin{abstract}
ÖZET
Bu makalenin konusunu, Ortadoğu coğrafyasında yer alan bazı ülkelerdeki suç oranları ve bu oranların yıllar bazında nasıl bir seyir izlediği hususu oluşturmaktadır. Uluslararası suç istatistikleri, Ortadoğu ülkelerindeki suç oranlarının, gelişmiş ülkelere kıyasla oldukça düşük olduğunu göstermektedir. Ancak son yıllarda, bu ülkelerde de bazı suçlarda artış yönünde bir kıpırdanmanın olduğu gözlemlenmektedir. Bu çerçevede çalı̧̧manın amacı, Ortadoğu ülkelerinde gerçekleşen suç oranlarının düzeyini ve bu oranların yıllar bazındaki değişimini ortaya koymaktır. Aynı şekilde bu makalede, Ortadoğu ülkelerindeki suç oranlarının niçin düşük seyrettiği ve son dönemlerde bazı ülkelerde ve suç türlerinde gerçekleşen artışın nedenlerinin neler olabileceği sorusuna yanıt aranmaya çalışlacaktır.
\end{abstract}

Anahtar Kelimeler: Ortadoğu Ülkelerinde Suç Oranları, Suç Oranlarındaki Değişim, Düşük Suçluluğun Nedeni

\begin{abstract}
The subject of this article, on the basis of crime rates and the years to see how these rates are matter in some of the countries in the Middle East. According to international crime statistics, crime rates in Middle Eastern countries is quite low compared to developed countries. However, in recent years, an increase in crimes is observed that some of these countries. The aim of this study, proportional to reveal change in the level of actual crime rates on the basis of years of Middle East countries. In the same way this article will be searching for answers to the question Middle east countries; why crime rate remained low in recent years and what could be reasons for the increase in some countries and types of crimes.
\end{abstract}

Key Word: Crime Rates in Middle East Countries, Changes in Crime Rates, Causes of Low Crime Rates.

\section{GİRIŞ}

Uluslararası suç istatistikleri, Ortadoğu coğrafyasında yer alan ülkelerde gerçekleşen suç oranlarının, gelişmiş olan ülkelerdeki suç oranlarından son derece düşük olduğunu göstermektedir. Ancak, suç istatistiklerinin güvenirliliğine ilişkin bazı çekincelerin de burada belirtilmesi gerekmektedir. Özellikle, bilinmediği veya bildirilmediği için kayda geçmeyen ve dolayısıyla istatistiklerinin göstermediği fakat gerçekte var olan, işlenmiş olan suçluluğu tanımlamak için kullanılan "siyah sayılar" sorununun, gelişmiş ülkeler için de söz konusu olmasına rağmen, Ortadoğu ülkeleri için daha ciddi bir problem teşkil ettiği söylenebilir. Diğer bir ifade ile gelişmiş ülkelere kıyasla Ortadoğu ülkelerinde işlenen suçların önemli bir oranının, bazı nedenlerle gerekli birimlere yansımadığı veya gizli kaldığı bir gerçektir. Bu nedenlerin başında, işlenen suç olaylarının, ilgili birimlere bildirilmemesi ve bazen de bildirilmesi durumunda bile gerekli özenin veya titizliliğin gösterilmeyerek ilgili kayitlara girilmemesi gelmektedir. $\mathrm{Bu}$ durum da, işlenen suçların tümünün istatistiklere yansımadığı ve dolayısıyla suç istatistiklerinin, işlenen tüm suçları göstermediği anlamına gelmektedir.

Özellikle geleneksel/dinsel yapının ve kurumların güçlü olduğu Ortadoğu toplumlarında işlenen suçların önemli bir oranı resmi kurumların dışında, aracı bireyler veya kurumlar sayesinde

\footnotetext{
* Prof. Dr. Frrat Üniversitesi, İnsani ve Sosyal Bilimler Fakültesi, Sosyoloji Bölüm, ELAZIĞ mail: zkizmaz@,firat.edu.tr

* * Bu makale, Fırat Üniversitesi Orta Doğu Araştırmaları Merkezi Sosyoloji Şubesi tarafindan 28 - 30 Haziran 2012

Tarihinde düzenlenen Uluslararası Ortadoğu Sosyolojisi Kongresinde sunulan bildirinin genişletilmiş halidir.
} 


\section{F.Ü. Sosyal Bilimler Dergisi 2013-24/1}

çözüme kavuşturulmaktadır. Bu durum da, işlenen tüm suçların bir şikâyet konusu olarak resmi kurumlara yansımaması ile sonuçlanmaktadır. İşlenen suçların tümünün gerekli veya ilgili yerlere bildirilmemesi veya istatistiklere yansımamasının başka nedenleri de bulunmaktadır. Burada işlenen suçların tümünün istatistiğe yansımamasının önde gelen bazı nedenleri olarak; a) cinsel taciz ve tecavüz gibi bazı suçların utanma ve çekingenlik duygusunu içermesi, b) yaralama veya aşırma türü bazı hırsızlık suçları gibi eylemlerin basit düzeyde görülmesi ve dolayısıyla bildirilme gereğinin duyulmaması c) suçlunun, suç mağduruna olan yakınlığg/akrabalığı veya ondan duyulan çekinme/korkma, d) suçu kayda geçiren memurların bu konuda gerekli özen ve titizliği göstermemeleri, e) işlenen suç oranlarını düşük göstermek gibi bir yaklaşımı resmi bir politika olarak benimseyen iktidarların tutumları gibi hususlar belirtilebilir. Suçların karanlıkta veya gizli kalması olarak tanımlanan suç istatistiklerine ilişkin bu problem, hiç kuşkusuz sadece Ortadoğu ülkeleri ile sınırlı bir husus değildir. Gelişmiş ülkelerde de buna benzer bir sorunun varlığına rağmen, ancak sorunun boyutunun Ortadoğu ülkelerinde daha yoğun olarak var olduğu bir gerçektir.

$\mathrm{Bu}$ çerçevede gelişmiş olan batı ülkelerine kıyasla gelişmekte olan Ortadoğu ülkelerinde işlenen suçların ortaya çıkarılmama veya çıkmama oranın çok daha yüksek olduğunu tahmin etmek güç değildir. Bu nedenle suç istatistiklerinin, işlenen suç oranlarını gerçekçi ve güvenilir olarak yansıtmaktan son derece uzak olduğu söylenebilir. Yine de, sosyo-kültürel yapı açısından Ortadoğu ülkelerinde gerçekleşen suç oranlarının gelişmiş ülkelere kıyasla daha az gerçekleştiği de bir gerçektir.

Tüm güvenirlilik kaygısına rağmen, söz konusu istatistiklerin işlenen suç oranları hakkında bilgi vermesi açısından önem taşıdığı ve bu nedenle bilimsel çalışmalarda kullanılması gerekliliği inkâr edilemez. Bu araştırmaya ilişkin olarak Ortadoğu ülkelerindeki suç istatistiklerine ilişkin belirtilecek diğer bir husus da, bu ülkelerde suç istatistiklerinin düzenli bir şekilde yayınlanmamasıdır. Öyle ki, bazı ülkeler ve belirli yıllar için suç istatistiklerini bulmak veya elde etmek mümkün değildir. Bu durum da, ülkeler ve yıllar bazında düzenli bir karşılaştırma yapmayı olanaksız kılmaktadır. Bu nedenle aşağıda verilen tablolarda (özellikle 1. ve 2. tablolarda) ülkelerin suç oranlarına ilişkin belirtilen yıllar farklılık arz edebilmektedir. Bu makalede kullanılan veriler, Birleşmiş Milletler Uyuşturucu ve Suç Ofisi (United Nations Office on Drugs and CrimeUNODC ) tarafından yayınlanan suç istatistikleri ile yine aynı şekilde UNODC ve Birleşmiş Milletlere bağlı Avrupa Suç Önleme ve Kontrolü Enstitüsü (HEUNI) 'ın birlikteliği ile yayınlanan "Uluslararası Suç ve Kriminal Adalet İstatistikleri" (Internatioanl Statistics on Crime and Criminal Justice )'nden alınmıştır.

Burada iki temel saptama yapmak gerekmektedir: Birinci saptama, Ortadoğu veya İslam ülkelerinde işlenen suç oranlarının (cinayet suçları hariç) gelişmiş diğer ülkelere kıyasla oldukça düşük düzeyde gerçekleşmesidir. İkinci saptama ise, söz konusu ülkelerde modernleşme süreci ile birlikte bazı suç oranlarının giderek artma eğilimi sergilemesidir. Diğer bir ifade ile bazı Ortadoğu ülkelerinde suç oranlarının düşük olmasına rağmen, günümüzde bir artma eğilimi içerisine girdiğini söylemek mümkündür. Örneğin İran'da hem de şiddet suçları hem de mala yönelik suçlar giderek artmaktadır. 1996 yılında 100.000 kişide 120 kişi şiddet suçu işlerken, bu oran 2003 yılında 100.000 kişi de 150 kişiye çıkmıştır. 1997-2005 yılları arasında yaklaşık olarak 9 yıl içerisinde ise mala yönelik suçlarda ise, \% 100 bir artış kaydedilmiştir (Haddad ve Moghadam, 2011).

$\mathrm{Bu}$ çalışmada ilkin, Ortadoğu ülkelerinde işlenen suç oranları ile gelişmiş olan bazı ülkelerde işlenen suç oranları (yıllar bazında bazı farklılıklar gösterse de) karşılaştırmalı bir şekilde verilecektir. Bu karşılaştırma, gelişmekte olan Ortadoğu ülkeleri ile gelişmiş batı ülkelerindeki suç oranları arasındaki farkı görmek açısından önem taşımaktadır. Ayrıca burada düşük suçluluk oranın nedenleri üzerinde durulacaktır. Akabinde de, Ortadoğu ülkelerinde yıllar bazında suç oranlarında nasıl bir değişmenin meydana geldiği (artma-azalma) konusu üzerine odaklanılacak ve bu değişimin yönünün nedenleri üzerinde- kısmen de olsa- durulmaya çalışılacaktır. 


\section{ORTADOĞU ÜLKELERİ İLE GELIŞMIŞ BAZI ÜLKELERDEKİ SUÇ ORANLARININ KARŞILAŞTIRILMASI}

Ortadoğu coğrafyası kapsamında hangi ülkelerin olduğu hususu bir tartışma konusudur. Bunun nedeni, Ortadoğu kavramının sadece coğrafi bir bölgeyi ifade etmemesi ve daha çok siyasal ve kültürel tanımlarının da öne çıkmasıyla ilintilidir. En dar anlamda coğrafik olarak Ortadoğu; Türkiye, İran ve Mısır üçgeni içerisinde kalan bölgeyi kapsadığı belirtilmektedir. Geniş kapsamlı tanımlama ise Ortadoğu; Ortadoğu ve bu devletlere komşu olan Müslüman ülkeleri (Kuzey Afrika, Afganistan, Sudan, Somali) de kapsayan tanımdır. Ancak üzerinde en çok uzlaşılan tanım ise Ortadoğu'nun, Arap ülkelerine, İran, İsrail ve Türkiye'nin de dahil edildiği bölge tanımıdır (bkz. Arı, 2005: 25). Bu çalışma kapsamında suç verilerine ulaşabildiğimiz, Birleşik Arap Emirlikleri, Misır, Türkiye, Katar, Lübnan, Ürdün, Umman, Kuveyt, Tunus, İran, Suudi Arabistan ve Bahreyn gibi Ülkeler ele aldık. Bu ülkelerin önde gelen bir özelliği, Lübnan dışında çoğunluğunun Müslüman olmasıdır. Etnik olarak da, İran ve Türkiye dışında diğer Ortadoğu ülkelerinin çoğunluğunun Arap halkından oluşmasıdır.

Gelişmiş batı ülkelerinde (ABD, İngiltere, Hollanda, Kanada, Belçika, İsveç, İsviçre gibi) özellikle 1960'lı yılların başından 90'lı yılların sonlarına kadar suç oranlarında ciddi artışlar yaşanmıştır (Fukayama, 1999). Son dönemlere gelindiğinde de gelişmiş bazı ülkelerde suç oranlarındaki artışların yerini görece bir durağanlık- yer yer ve bazı suç türlerinde azalmalaralmıştır. İslam dinin etkili olduğu Ortadoğu ülkelerinde ise aşağıdaki tablodan da açık bir şekilde görülebileceği gibi son yıllara ilişkin gerçekleşen suç oranları son derece düşük düzeyde seyretmektedir.

Tablo 1: Ortadoğu Ülkeleri ile Gelişmiş Bazı Ülkelerdeki Şiddet Suçlarında (cinayet, yaralama, tecavüz, gasp) 100.000 Nüfusta Kişi Başına Düşen Suç Oranı

\begin{tabular}{|c|c|c|c|c|}
\hline $\begin{array}{l}\text { ÜLKELER } \\
\text { ORTADOĞU ÜLKELERİ }\end{array}$ & Cinayet $^{1}$ & Ciddi Yaralamalar ${ }^{2}$ & Gasp-Soygun $^{3}$ & Cinsel Şiddet ${ }^{4}$ \\
\hline Türkiye & $4.6(2006)$ & $201,2(2006)$ & $29,7(2006)$ & $2.5(2006)$ \\
\hline Misır & $1.2(2009)$ & $0,1(2005)$ & $0,7(2006)$ & $0,3(2006)$ \\
\hline Katar & $0.9(2009)$ & $41,7(2004)$ & $2,9(2004)$ & $1.6(2004)$ \\
\hline Suriye & $3.0(2008)$ & $29,3(2006)$ & $4,5(2006)$ & $0.6(2006)$ \\
\hline Lübnan & $2.2(2010)$ & $10,1(2006)$ & $3,6(2006)$ & $0.5(2006)$ \\
\hline Ürdün & $1.8(2006)$ & $285,6(2006)$ & $14,(2006)$ & $1.9(2006)$ \\
\hline Umman & $0.7(2008)$ & $69,9(2007)$ & $5,2(2007)$ & $4.6(2002)$ \\
\hline Kuveyt & $2.2(2009)$ & $26,9(2006)$ & $28,4(2006)$ & \\
\hline Yemen & $4.2(2009)$ & $0,1(2009)$ & $33,6(2009)$ & $0.4(2000)$ \\
\hline Birleşik Arap Emirlikleri & $0.8(2006)$ & $16,3(2006)$ & $11,9(2006)$ & $1.7(2006)$ \\
\hline Irak & $2.0(2008)$ & & & \\
\hline Tunus & $1.1(2008)$ & & & $3.2(2002)$ \\
\hline İran & $3.0(2009)$ & & & \\
\hline Suudi Arabistan & $1.0(2007)$ & & & $0.3(2002)$ \\
\hline Bahreyn & $0.6(2008)$ & $425,8(2006)$ & & \\
\hline \multicolumn{5}{|l|}{ GELIŞMİS BAZI ÜLKELER } \\
\hline Amerika Bir. Dev. & $5.0(2009)$ & $291,8(2006)$ & $150,2(2006)$ & $30.2(2006)$ \\
\hline Birleşik Krallık & $1.2(2009)$ & $939,4(2006)$ & $188,7(2006)$ & $25.6(2006)$ \\
\hline Kanada & $1.8(2008)$ & $173,8(2006)$ & $106,2(2006)$ & $68.2(2006)$ \\
\hline Almanya & $0.8(2010)$ & $618,9(2006)$ & $65,1(2006)$ & $9.9(2006)$ \\
\hline
\end{tabular}

\footnotetext{
${ }^{1}$ Cinayet suçu burada, başka bir kişi tarafindan kişinin uğradığı kasıtlı saldırı sonucunda gerçekleşen ölüm olaylarını kapsamaktadır.

${ }^{2}$ Ciddi bedensel yaralanma ile sonuçlanan bir başka kişinin vücuduna karşı fiziksel saldırı (cinsel nitelikteki saldırılar hariç) suçlarını içermektedir.

${ }^{3}$ Soygun, bir kişinin güç kullanarak veya güç kullanma tehdidinde bulunarak bir kişinin malına el koyması anlamına gelir; saldırıp soyma ve şiddet kullanılarak gerçekleştirilen hırsızlıklar bu kapsamdadır. Ancak cep hırsızlığı ve haraca bağlamak bu suç kapsamına girmez.

${ }^{4}$ Cinsel şiddet, çocuklara karşı işlenen cinsel suçlar da dahil olmak üzere, tecavüz ve cinsel saldırı suçlarını içermektedir.
} 


\begin{tabular}{|l|l|l|l|l|}
\hline Fransa & $1.4(2008)$ & $267,8(2006)$ & $207,2(2006)$ & $17.3(2004)$ \\
\hline İsvec & $1.0(2009)$ & $847,2(2006)$ & $94,4(2006)$ & $40.6(2006)$ \\
\hline Norveç & $0.6(2009)$ & $68,2(2006)$ & $29,7(2006)$ & $18.0(2006)$ \\
\hline Danimarka & $0.9(2009)$ & $213,6(2006)$ & $48,7(2006)$ & $9.7(2006)$ \\
\hline Hollanda & $1.1(2009)$ & $352,0(2006)$ & $11,3(2006)$ & $8.7(2006)$ \\
\hline İtalya & $1.0(2009)$ & $100,1(2006)$ & $120,4(2006)$ & $7.7(2006)$ \\
\hline Rusya Federasyonu & $11.2(2009)$ & $35,9(2006)$ & $249,0(2006)$ & $4.8(2000)$ \\
\hline Japonya & $0.5(2008)$ & $51,4(2006)$ & $4,0(2006)$ & $1.5(2006)$ \\
\hline
\end{tabular}

(Kaynak: Cinayet suçları için; 2011 Global Study on Homicide, 90-95; Diğer suçlar için ise Harrendor, Heiskanen and Malby, 2010)

Yukarıdaki tabloya bakıldığında; “cinayet suçlarının” en çok Rusya Federasyonu'nda işlendiği (100 bin nüfusta kişi başına düşen oran 11.2) görülmektedir. Bunu ABD (100.000 nüfusta 5.0), Türkiye (100.000 nüfusta 4.6) ve Yemen (100.000 nüfusta 4.2) izlemektedir. Tabloda yer alan Ortadoğu ülkeler kategorisi içerisinde iki ülkenin cinayet suç oranlarının yüksek olması son derece dikkat çekicidir. Aynı şekilde cinayet suçları kategorisine bakıldığında, Suriye, İran, Lübnan, Kuveyt gibi Ortadoğu ülkelerinde cinayet suçunun işlenme oranı diğer tabloda yer alan çoğu ülkelerden - Rusya ve Amerika hariç- yüksektir. Tabloda yer alan gelişmiş batı ülkeler içerisinde, ABD hariç, 100.000 nüfusta kişi başına düşen cinayet sayısının 2'yi aştığı ülke bulunmamaktadır. Çoğu ülkelerde 100.000 nüfusta kişi başına düşün cinayet sayıs1 1.5 kişiden bile düşüktür (bkz. İngiltere, Almanya, Fransa, Norveç, Hollanda, İtalya, Danimarka). Bu nedenle yukarıdaki tablonun çarpıcı bulgusu, gelişmiş ülkelerle karşılaştırıldığında Ortadoğu ülkelerinde 100.000 kişide işlenen cinayet suç oranın daha yüksek gerçekleşmiş olmasıdır. Ortadoğu ülkelerinde veya geleneksel toplumlarda genelde cinayet olaylarının daha fazla meydana geldiği bir gerçektir. Özellikle yakın/akraba ilişkilerinin ve namus, intikam/öç alma duygusunun güçlü olduğu toplumlarda daha sık cinayet olaylarının yaşandığı söylenebilir.

"Ciddi yaralamalar" suç kategorisine bakıldığında ise, genel olarak gelişmiş ülkelerdeki oranlarının oldukça yüksek olduğu gözlemlenmektedir. Bu ülkeler arasında özellikle ABD ve İsveç’teki oranlar yüksektir. Gelişmiş ülkeler arasında yaralama suçunun en az gerçekleştiği ülkeler ise Rusya, Japonya ve Norveç'tir. İslam ülkeleri içerisinde ise yaralama suçlarının en çok gerçekleştiği ülkelerin başında Bahreyn, Ürdün ve Türkiye gelmektedir.

Aynı şekilde gasp ve tecavüz suçlarında da, gelişmiş ülkelerde gerçekleşen oranlar Ortadoğu ülkelerine kıyasla son derece yüksektir. Rusya, Fransa, Birleşik Krallık ve ABD'de bu suçun işlenme oranı diğer ülkeler içerisinde en yüksektir. Ortadoğu ülkeler kategorisinde ise bu suçun en çok işlendiği ülkelerin başında, Yemen, Türkiye ve Kuveyt gelmektedir. Cinsel şiddet suçları (tecavüz gibi) kategorisinde de, Ortadoğu ülkeleri düzeyinde suçluluk oranının düşük düzeyde gerçekleşen ülke Japonya'dır. Diğer gelişmiş ülkelerde cinsel şiddet suçu, 100.000 nüfusta kişi başına düşen suçluluk oranı son derece yüksektir. Ancak burada Umman, Tunus ve Türkiye gibi ülkelerde diğer Ortadoğu ülkelerine kıyasla daha fazla bu suçun işlendiği gözlemlenmektedir. 
Ortadoğu Ülkelerinde Suç Oranlarına Genel Bir Baklş.

Tablo 2: Ortadoğu Ülkeleri ile Gelişsmiş Baz Ülkelerdeki Mala Yönelik Suçlarda (konut hırsızlığı, genel hırsızlık, uyuşturucu ile ilintili Suçlar) 100.000 Nüfusta Kişi Başına Düşen Suç Oranı

\begin{tabular}{|c|c|c|c|}
\hline ÜLKELE & $\begin{array}{c}\begin{array}{c}\text { Konut Hırsızlı̆̆ } \\
\text { (Burglary }^{5}\end{array} \\
\end{array}$ & $\begin{array}{c}\text { Genel Hirsizlık } \\
\text { (Theft) }\end{array}$ & $\begin{array}{l}\text { Uyuşturucu İle } \\
\text { İlintili Suçlar }{ }^{7} \\
\end{array}$ \\
\hline \multicolumn{4}{|l|}{ ORTADOĞU ÜLKELERİ } \\
\hline Türkiye & $223.5(2006)$ & $248,7(2006)$ & $14,6(2006)$ \\
\hline Misır & $5.8(2009)$ & $46,3(2006)$ & $37,8(2006)$ \\
\hline Katar & $56.4(2004)$ & $106,6(2006)$ & $23,0(2004)$ \\
\hline Suriye & $14.7(2006)$ & $24,7(2007)$ & $13,1(2005)$ \\
\hline Lübnan & & $94,6(2005)$ & \\
\hline Ürdün & & $162,8(2005)$ & \\
\hline Umman & & $235,4(2007)$ & $17,5(2007)$ \\
\hline Kuveyt & & $398,1(2006)$ & \\
\hline Birleşik Arap Emirlikleri & $58.9(2004)$ & $301,7(2004)$ & $22,9(2006)$ \\
\hline Tunus & $81.3(2000)$ & & \\
\hline İran & & $159,4(2004)$ & \\
\hline Suudi Arabistan & $0.1(2002)$ & & \\
\hline Bahreyn & $48.4(2006)$ & $783.8(2007)$ & $107,2(2006)$ \\
\hline \multicolumn{4}{|l|}{ GELİ̧MIŞ BAZI ÜLKELER } \\
\hline Amerika Birleşik Devletleri & $733.2(2006)$ & $2.215,4(2006)$ & \\
\hline Birleşik Krallık & $1157.7(2006)$ & $3.261,8(2006)$ & $361,5(2006)$ \\
\hline Kanada & $610.7(2009)$ & $1.945,9(2006)$ & $294,8(2006)$ \\
\hline Almanya & $669.6(2006)$ & $2.573,5(2006)$ & $309,5(2006)$ \\
\hline Fransa & $563.8 .4(2006)$ & $1.340,6(2006)$ & $246,8(2006)$ \\
\hline İsveç & $1096.2(2006)$ & $4.569,8(2006)$ & $733,6(2006)$ \\
\hline Norveç & $485.6(2006)$ & $2.859,5(2006)$ & $891,7(2006)$ \\
\hline Danimarka & $1315.2(2006)$ & $3.049,1(2006)$ & $374,2(2006)$ \\
\hline Hollanda & $427.8(2006)$ & $3.500,7(2006)$ & $99,8(2006)$ \\
\hline İtalya & $190.3(2004)$ & $1.932,8(2006)$ & $54,8(2006)$ \\
\hline Rus Federasyonu & $278,4(2007)$ & $1.170,7(2006)$ & \\
\hline Japonya & $162.5(2006)$ & $641,5(2006)$ & $16,9(2006)$ \\
\hline
\end{tabular}

(Kaynak: Harrendorf, Heiskanen and Malby, 2010)

Mala yönelik suçlara ilişkin yukarıdaki tabloya da bakıldığında; her üç suç türünde de, gelişmiş ülkelerdeki suç oranlarının, Ortadoğu coğrafyasında yer alan ülkelere kıyasla son derece yüksek olduğu görülmektedir. Örneğin, konut hırsızlığı suçlarında Danimarka 100.000 nüfusta kişi başına düşen suç sayısı 1315.2, Birleşik Krallık'ta 1157.7 olurken, Ortadoğu ülkeleri kategorisi içerisinde en yüksek oran 223.5 ile Türkiye olmaktadır. Diğer ülkelerde ise bu suçun işlenme oranı çok daha düşük düzeydedir. Genel olarak hırsızlık suçlarında ise örneğin İsveç, Hollanda, Danimarka, Birleşik Krallık gibi ülkelerde 100.000 nüfusta kişi başına düşen suçluluk oranı 3000 'den daha yüksek gerçekleşirken, Ortadoğu ülkeleri içerisinde en yüksek değerin gerçekleştiği Kuveyt ve Birleşik Arap Emirlikleri gibi ülkelerde bile 400'den daha küçük düzeyde gerçekleşmiştir. Gelişmiş ülkelerde uyuşturucu ile ilintili suçların işlenme oranı da, Japonya hariç, Ortadoğu ülkelerine kıyasla oldukça yüksektir.

Serajzadeh, İslam ülkelerindeki suç oranlarının düşük düzeyde gerçekleşmesini, bu ülkelerde benimsenen ve uygulanan İslam inancı ve pratiği ile açıklamaktadır (Serajzadeh, 2001:111). Ortadoğu ülkelerinde suç oranlarının düşük olması iki genel faktör başlı̆̆ı altında çözümlenebilir. Birincisi, suç oranları üzerinde pozitif tarzda etki edecek gelişme düzeyinin düşük gerçekleşmesi ve ikincisi ise İslam ceza hukukunun katı oluşu. Birinci neden, toplumsal gelişme veya modernleşme dinamikleri ile ilintilidir. Kültürel, ekonomik, teknolojik, demografik, sosyal ve

\footnotetext{
${ }^{5}$ Güç kullanmak da dahil bir kazanç elde etmek amacıyla eşya çalmak için izinsiz olarak bir binaya (ev, aparman, fabrika, dükkan gibi ) girmek anlamında kullanılmıştır.

${ }^{6}$ Bir şeyi güç kullanmaksızın ele etmek amacıyla her hangi birini veya ekonomik kuruluşu mahrum etmek. Bu suç türü; haneye tecavüz, soygunculuk ve taşıt hırsızlığını içermez.

${ }^{7}$ Uyuşturucu ile ilgili suçlar kapsamında; uyuşturucu maddenin ekilmesi, üretimi hazırlanması; dăğıımı; alımı, satımı, sevkiyatı, teslimiyeti, ulaştırılması dahil tüm kasıtlı eylemleri içermektedir.
} 


\section{F.Ü. Sosyal Bilimler Dergisi 2013-24/1}

siyasal gibi toplumsal yaşamın tüm alanlarındaki değişimi ifade eden modernleşme aynı zamanda geleneksel yaşam tarzlarını ve kurumlarını da radikal bir şekilde dönüştürmektedir. Aynı şekilde modernleşmenin kapsamı, hızı ve süreci ile ilintili olarak da ortaya çıkan çok sayıda sorunların (aile sorunları, dinsel kurumunun zayıflaması, bireyselciliğin gelişmesi, enformel denetimin zayıflaması, göreli yoksulluk ve kent yaşamının getireceği sorunlar gibi) baş göstermesi, doğrudan suç oranlarının artışında etkili olabilmektedir. Bu çerçevede, son yıllara kadar modernleşme veya değişme dinamiklerinin son derece zayıf olduğu ve dolayısıyla geleneksel yapının ve enformel kontrolün güçlü olduğu Ortadoğu ülkelerinde, suç oranlarının daha az gerçekleşmesinin anlaşılır nedenleri bulunmaktadır. Ortadoğu ülkelerinde düşük suçluluğun ikinci nedeni ise, gerek kültürel olarak deneyimlenen İslam dinin suç eylemlerini olumsuzlayan içerimi veya dinin gelenekler üzerinden yaşam tarzının önemli bir belirleyeni olması ve gerekse suç olarak tanımlanan eylemelere karşı İslam hukukundan esinlenerek geliştirilmiş sert bir cezalandırma sisteminin caydırıcı niteliğgi ile ilintili olduğu söylenebilir.

Serajzadeh, (2001:114) İslami olarak nitelendirilen ülkelerde suç oranlarının düşük düzeyde gerçekleşmesini, söz konusu ülkelerin bazı sosyo- kültürel özellikleri ile ilişkili ele alındığını ileri sürmektedir. O söz konusu unsurları şu şekilde belirtmektedir.

1. İslam ülkeleri bir dereceye kadar homojen olarak nitelendirilebilecek ülkelerdir. Özellikle Ortadoğu ülkelerinde nüfusun çoğunluğu dinsel ve aynı zamanda da ırksal olarak homojen/tekdüze bir nitelik sergilemektedir. Mevcut etnik farklılıklar da temelde, ulusal kimlik için güçlü bir unsur olan dinsel harmoninin/uyumunun gölgesinde kalmaktadır.

2. İslam ülkelerinde aile bağl1lıkları ve aile kurumu hala güçlülügünü muhafaza etmektedir. Modern kentlerde aile ağı ve bağl1lı̆̆ devam etmektedir. Bu da aile kurumu tarafindan sağlanan sosyalleşme ve sosyal desteğin devam ettiği anlamına gelmektedir.

3. İslam ülkelerinde bireysel haklardan çok bireyin sorumluluğu üzerine daha çok vurgular yapılmaktadır. Burada bireylerin çıkarları, grup çıkarlarından daha az önemde görülmektedir. Bu çerçevede sosyal fayda amacı gözetilerek bireylerin kişisel çıkar ve taleplerini bastıran dinsel, geleneksel ve siyasal kurumların bu müdahaleleri haklı ve meşru olarak değerlendirilmektedir.

4. Bu unsurların sonucu olarak İslam ülkelerinde kamuoyunun, suç davranışına daha az toleranslı olduğu ve bu ülkelerdeki kamuoyunun diğer ülkelere kıyasla suçluların daha fazla sert bir şekilde cezalandırılmaları yanlısı oldukları gibi hususlar belirtilebilir (bkz. Serajzadeh, 2001:114). Özetle bu ülkelerdeki düşük suçluluk oranı; ırksal ve dinsel homojenlik, aile ağ yapısının korunması, haklardan çok bireysel sorumluluklar vurgusu ve suça daha az toleransın gösterilmesi gibi faktörlerle açıklanmaktadır.

Suçların gelişmiş ülkelerde daha yaygın işlenmesi, bireylerin daha çok suça eğilimli olarak yetişmelerinde etkili olan koşulların fazlalılığı (boşanmalar, sosyalleşme sorunları, suç alt-kültürün varlığı, sosyal örgütsüzlük gibi) ve artan suç firsatları ile ilişkilidir. İslam toplumlarında, formel ve enformel denetimin sıkı ve güçlü bir şekilde varlığı gerek mala yönelik gerekse de şiddet suçlarının daha az işlenmesinde etkili olduğu söylenebilir. Türkiye'de suç oranlarının diğer İslami olarak nitelendirilen ülkelerden daha fazla işlenmesinin önde gelen temel nedeni, Türkiye'nin diğer ülkelere kıyasla daha güçlü bir şekilde değişim ve dönüşüm sürecini yaşamış olmasıdır. Ülkemizde son dönemlerde toplumsal, siyasal, kültürel, ekonomik ve kültürel alanda radikal ve köklü değişimler gerçekleşmiştir. Özellikle 90'li yıllardan sonra giderek hız kazanan modernleşme süreci, toplumda derin ve köklü değişmeler yaratmıştır. Ülkemizde de son dönemlerde artan suç oranlarının bu değişim süreci ile çok yakından ilintili olduğu söylenebilir.

Çağdaş suç kuramcılarından Braithwaite, enformel denetim unsurlarının suçluluktaki caydırıcı etkisinin, formel kurum ve süreçlerden daha etkili olduğunu ileri sürmektedir. $O$, cemaat değerlerinin güçlü olduğu Japonya, Çin ve benzeri ülkelerdeki suç oranlarının, ABD gibi bireyselciliğin geliştiği ülkelere kıyasla daha az gerçekleşmesinin temelinde de söz konusu ülkelerdeki güçlü enformel değer ve denetime ilişkin bu unsurları görmektedir (Bkz. Barak, 1998: 
203). Ona göre, toplumcu değerlerin güçlü olduğu cemaat yapılarında, bireysel çıkarı ve konforu gözeten bireyselciliğin aksine, yoğun düzeyde karşılıklı bir bağımlılık ilişkisi, karşılıklı güven ve sorumluluk duygusu bulunmaktadır. Bu sorumluluk duygusu, bireylerin toplumsal bağlılığını sağlayan temel bir işleve sahiptir (Barlow, 1993: 583). Aynı şekilde Braithwaite'a göre, suç veya şiddet olayları, aile ve toplumculuk değerlerinin güçlü olduğu toplumlarda daha iyi kontrol edilebilir (Braithwaite, 1989: 5-9). Suç ve sapkın eylemler üzerinde enformel denetim faktörlerinin, formel unsurlara kıyasla daha fazla caydırıcı olduğunu belirten Braithwate, caydırıcılıkla ilgili yapılan araştırmaların, cezanın kesinliği ile suç arasında mantıksal olarak bir ilişkiyi ortaya koymasına karşın, bulgusal olarak bu ilişkinin çok az desteklendiğini ileri sürmektedir. Diğer bir ifade ile Braithwaite; aile üyeleri, akrabalar, arkadaşlar veya birlikte olunan gruplar tarafindan empoze edilen değerler, müeyyideler ve geleneksel denetim unsurları, uzaktan gerçekleştirilen yasal otoriteye oranla suçlulukta daha caydırıcı bir etkiye sahip olduğunu ileri sürmektedir. Bu, yakın aile üyeleri ile sağlanan ve dolayısıyla gözetlenen itibar olgusunun, kriminal adalet sisteminin yaptırımından daha etkili işlediği anlamına gelmektedir (Braithwaite, 1989: 69).

Özetle Braithwaite, bazı Asyatik toplumlardaki suç oranlarının düşük düzeyde gerçekleşmesini, söz konusu toplumların toplumsal yapısı ile açıklamaktadır. O’na göre Asyatik toplumların; karşılıklı dayanışma, ailecilik ve toplumculuk unsurlarını içeren bir toplumsal yapıya sahip olmaları ile düşük suçluluk arasında bir ilişki bulunmaktadır (Zhang, 1995: 248). Ortadoğu ülkelerinde suç oranlarının düşük düzeyde gerçekleşmesi, Braithwaite'nin bu yaklaşımı çerçevesinde de ele alınabilir.

$\mathrm{Bu}$ çerçevede hiç kuşkusuz, aşağıdaki tablolarda da görülebileceği gibi bazı Ortadoğu ülkelerinde belirli suç oranlarının artmasında da, bu ülkelerde gerçekleşen değişim süreci ile birlikte geleneksel değerlerin ve bununla ilişkili olan enformel denetim unsurlarının zayıflamasının ciddi bir etkisi olduğu söylenebilir.

\section{ORTADOĞU ÜLKELERINDE SUÇ ORANLARINDA YILLAR BAZINDA MEYDANAN GELEN DEĞİSME}

Günümüzde gelişmiş olarak gösterilen ülkelerde, modernleşme süreci yaşadıkları geçmiş dönemlerde suç oranlarında ciddi artışlar kaydedilmiş ve suç kalıplarında değişmeler gözlemlenmiştir. Günümüzde de modernleşme sürecine giren diğer bir ifade ile gelişmekte olan ülkelerde de, gelişme dinamikleri ve hızına bağlı olarak bazı suçların oranlarında da artışların gerçekleştiği tespiti yapılmaktadır. Bu çerçevede, toplumsal ve siyasal bir hareketlenme içerisinde bulunan Ortadoğu coğrafyasında modernleşme dinamiklerinin gelişmesi ve güçlenmesi ile birlikte suç oranlarında ve niteliğinde de bazı değişmelerin yaşanacağı tahmin edilmektedir.

Aşağıda, ulaşabildiğimiz bazı ülkelere ilişkin suç verileri yer almaktadır. Söz konusu ülkelerde 100.000 nüfusta yıllar bazında kişi başına düşen suç oranı verilerek, yıllar bazında oranlarda nasıl bir dağılım sergilediğine bakılacaktır. 


\section{F.Ü. Sosyal Bilimler Dergisi 2013-24/1}

Tablo 3: Bazı Ortadoğu Ülkelerinde İşlenen Soygun/Gasp Suçlarında 100.000 Nüfusta Kişi Başına Düşen Suç Oranı

\begin{tabular}{|l|c|c|c|c|c|c|}
\hline \multirow{2}{*}{ ÜLKELER } & \multicolumn{7}{|c|}{ Soygun/Gasp } \\
\cline { 2 - 7 } & Yll & Rakam & Oran & Yll & Rakam & Oran \\
\hline Mısır & 2003 & 337 & $\mathbf{0 . 5}$ & 2009 & 732 & $\mathbf{0 . 9}$ \\
\hline Ürdün & 2005 & 619 & $\mathbf{1 1 . 6}$ & 2006 & 802 & $\mathbf{1 4 . 6}$ \\
\hline Kuveyt & 2004 & 426 & $\mathbf{1 9 . 5}$ & 2009 & 657 & $\mathbf{2 4 . 8}$ \\
\hline Lübnan & 2005 & 419 & $\mathbf{1 0 . 3}$ & 2006 & 146 & $\mathbf{3 . 6}$ \\
\hline Umman & 2007 & 133 & $\mathbf{5 . 2}$ & 2008 & 255 & $\mathbf{9 . 7}$ \\
\hline Katar & 2003 & 21 & $\mathbf{3 . 2}$ & 2004 & 21 & $\mathbf{2 . 9}$ \\
\hline Suriye & 2003 & 505 & $\mathbf{2 . 9}$ & 2008 & 870 & 4.4 \\
\hline Türkiye & 2003 & 16.679 & $\mathbf{2 5 . 1}$ & 2008 & 7695 & $\mathbf{1 0 . 8}$ \\
\hline Birleşik Arap Emir. & 2003 & 396 & $\mathbf{1 1 . 6}$ & 2006 & 557 & $\mathbf{1 1 . 9}$ \\
\hline Yemen & & & & 2009 & 732 & $\mathbf{3 3 . 6}$ \\
\hline
\end{tabular}

(Kaynak: http://www.unodc.org/unodc/en/data-and-analysis/statistics/data.html)

Yukarıdaki tabloda dikkat çeken verilerden biri özellikle Kuveyt, Ürdün ve Umman gibi ülkelerde gasp suçlarında ciddi artışların gerçekleşmiş olmasıdır. İkinci husus ise, Türkiye ve Lübnan'da bu suç olaylarında gözlemlenen ciddi düşüşlerdir. Türkiye'de gasp suçlarında 2006 yılı hariç diğer tüm yıllarda giderek bir düşüş gözlemlenmiştir. Bu düşüşün önde gelen nedenleri olarak, geçmiş yıllarda gasp suçuna ilişkin yapılan hukuki düzenleme (cezasının ağırlaştırılması) ve bu suçları önleme konusunda alınan yeni tedbirler (özellikle güven timinin oluşturulması) belirtilebilir. Lübnan için ise istatistiklerde sadece bu iki yıla ilişkin veri bulunmaktadır. Bu nedenle, burada sadece bu 2 yıla ilişkin bir azalmadan söz edilebilir.

Tablo 4: Bazı Ortadoğu Ülkelerinde İşlenen Hırsızlık Suçlarında 100.000 Nüfusta Kişi Başına Düşen Suç Oranı

\begin{tabular}{|c|c|c|c|c|c|c|}
\hline \multirow{2}{*}{ ÜLKELER } & \multicolumn{6}{|c|}{ Hirsızlık } \\
\hline & Yil & Rakam & Oran & Yil & Rakam & Oran \\
\hline Misir & 2003 & 30.116 & 42.1 & 2009 & 28.036 & 35.2 \\
\hline Ürdün & 2005 & 7.068 & 132.3 & 2006 & 8945 & 162,8 \\
\hline Kuveyt & 2004 & 7.230 & 330.2 & 2008 & 9399 & 368.8 \\
\hline Lübnan & 2005 & 3.834 & 94.6 & 2004 & 1685 & 41.1 \\
\hline Umman & 2007 & 6.028 & 235.4 & 2008 & 5515 & 209.1 \\
\hline Katar & 2003 & 754 & 115.4 & 2006 & 1043 & 106.6 \\
\hline Suriye & 2003 & 12.349 & 70.6 & 2008 & 6509 & 33.1 \\
\hline Türkiye & 2003 & 66.405 & 100.1 & 2009 & 120.731 & 170.2 \\
\hline Birleşik Arap Emir. & 2003 & 10.802 & 317.6 & 2004 & 11.037 & 301.7 \\
\hline İran & 2003 & 104.746 & 153.9 & 2004 & 109.839 & 159.4 \\
\hline Yemen & & & & 2009 & 7829 & 33.6 \\
\hline
\end{tabular}

(Kaynak: http://www.unodc.org/unodc/en/data-and-analysis/statistics/data.html)

Tablodan Türkiye, Ürdün, Kuveyt ve İran hariç diğer Ortadoğu ülkelerinde genel hırsızlık suçlarında belirgin bir düşüş gözlemlenmektedir. Hırsızlık suç oranlarında artış ise en çok Türkiye' de gerçekleştiği dikkat çekmektedir. Türkiye'de 2003 yılında 100.000 nüfusta 100 kişi hırsızlık suçu işlerken bu oran 2009 yılında 170 kişiye yükselmiştir. Hırsızlık suç oranlarının artış gösterdiği diğer ülkeler ise sırasıyla Kuveyt, Ürdün ve İran'dır. 
Ortadoğu Ülkelerinde Suç Oranlarına Genel Bir Baklş.

Tablo 5: Bazı Ortadoğu Ülkelerinde İşlenen Cinsel Şiddet Suçlarında 100.000 Nüfusta Kişi Başına Düşen Suç Oranı

\begin{tabular}{|l|c|c|c|c|c|c|}
\hline \multirow{2}{*}{ ÜLKELER } & \multicolumn{6}{|c|}{ Cinsel Şiddet } \\
\cline { 2 - 7 } & Yll & Rakam & Oran & Yıl & Rakam & Oran \\
\hline Mısır & 2003 & 160 & $\mathbf{0 . 2}$ & 2009 & 273 & $\mathbf{0 . 3}$ \\
\hline Kuveyt & 2004 & 393 & $\mathbf{1 7 . 9}$ & 2009 & 509 & $\mathbf{1 9 . 2}$ \\
\hline Umman & 2008 & 132 & $\mathbf{5 . 2}$ & 2009 & 183 & $\mathbf{6 . 9}$ \\
\hline Suriye & 2008 & 70 & $\mathbf{0 . 4}$ & 2009 & 85 & $\mathbf{0 . 4}$ \\
\hline Türkiye & 2003 & 2858 & $\mathbf{4 . 3}$ & 2006 & 3300 & $\mathbf{4 . 8}$ \\
\hline Bahreyn & 2007 & 145 & $\mathbf{1 5 . 7}$ & 2008 & 175 & $\mathbf{1 6 . 6}$ \\
\hline Yemen & & & & 2009 & 269 & $\mathbf{1 . 2}$ \\
\hline
\end{tabular}

(Kaynak: http://www.unodc.org/unodc/en/data-and-analysis/statistics/data.html)

Yukarıdaki tabloda yer alan ülkelerde, 20003- 2009 yılları arasında işlenen cinsel şiddet suçlarında küçük düzeyde de olsa bir artış gerçekleşmiş̧ir. Ham verilere bakıldığında, bu suç türüne ilişkin ciddi artışların olduğu ancak bu rakamlar nüfusa oranlandığında dağılımın daha minimize olduğu gözlemlenmektedir.

Tablo 6: Bazı Ortadoğu Ülkelerinde İşlenen Konut Hırsızlıkları Suçlarında 100.000 Nüfusta Kişi Başına Düsşen Suç Oranı

\begin{tabular}{|l|c|c|c|c|c|c|}
\hline \multirow{2}{*}{ ÜLKELER } & \multicolumn{7}{|c|}{ Konut Hırsızlı̆̆ } \\
\cline { 2 - 7 } & Yıl & Rakam & Oran & Yıl & Rakam & Oran \\
\hline Mısır & 2003 & 3.312 & $\mathbf{4 . 6}$ & 2009 & 4.378 & $\mathbf{5 . 5}$ \\
\hline Katar & 2003 & 264 & $\mathbf{4 0 . 4}$ & 2004 & 403 & $\mathbf{5 6 . 4}$ \\
\hline Suriye & 2003 & 8 & $\mathbf{0 . 1}$ & 2008 & 807 & 4.1 \\
\hline Türkiye & 2003 & 65.721 & $\mathbf{9 9 . 1}$ & 2008 & 114.234 & $\mathbf{1 6 1 . 1}$ \\
\hline Birleşik Arap Emir. & 2003 & 1882 & $\mathbf{5 5 . 3}$ & 2004 & 2153 & $\mathbf{5 8 . 9}$ \\
\hline
\end{tabular}

(Kaynak: http://www.unodc.org/unode/en/data-and-analysis/statistics/data.html)

Genel hırsızlık tablosuna kıyasla konut hırsızlığında artışlar gerçekleşmiştir. Özellikle Türkiye, daha önceki genel hırsızlık tablosunda da olduğu gibi bu suç türünde de oldukça kayda değer bir artış kaydetmiştir. 7 yıl içersinde konut hırsızlığı Türkiye'de yaklaşık olarak 2.5 kat artmıştır.

Tablo 7: Bazı Ortadoğu Ülkelerinde Fiziksel Saldırı ile Gerçekleşen Ciddi Yaralama Suçlarında 100.000 Nüfusta Kişi Başına Düşen Suç Oranı

\begin{tabular}{|l|c|c|c|c|c|c|}
\hline \multirow{2}{*}{ ÜLKELER } & \multicolumn{5}{|c|}{ Ciddi Yaralama İle Sonuçlanan Fiziksel Saldırı Suçları } \\
\cline { 2 - 7 } & Yıl & Rakam & Oran & Yll & Rakam & Oran \\
\hline Mısır & 2003 & 31 & $\mathbf{0 . 0}$ & 2009 & 66 & $\mathbf{0 . 1}$ \\
\hline Ürdün & 2005 & 14.677 & $\mathbf{2 7 4 . 7}$ & 2006 & 15.694 & $\mathbf{2 8 5 . 6}$ \\
\hline Kuveyt & 2004 & 641 & $\mathbf{2 9 . 3}$ & 2009 & 686 & $\mathbf{2 5 . 9}$ \\
\hline Lübnan & 2005 & 1193 & $\mathbf{2 9 . 4}$ & 2006 & 412 & $\mathbf{1 0 . 1}$ \\
\hline Umman & 2008 & 1790 & $\mathbf{6 9 . 9}$ & 2009 & 2083 & $\mathbf{7 9}$ \\
\hline Katar & 2003 & 291 & $\mathbf{4 4 . 5}$ & 2004 & 298 & $\mathbf{4 1 . 7}$ \\
\hline Suriye & 2003 & 5390 & $\mathbf{3 0 . 8}$ & 2005 & 6157 & $\mathbf{3 3 . 3}$ \\
\hline Türkiye & 2003 & 91.997 & $\mathbf{1 3 8 . 7}$ & 2009 & 154.313 & $\mathbf{2 1 7 . 6}$ \\
\hline Birleşik Arap Emir. & 2003 & 2253 & $\mathbf{6 6 . 2}$ & 2006 & 758 & $\mathbf{1 7 . 6}$ \\
\hline
\end{tabular}

(Kaynak: http://www.unodc.org/unodc/en/data-and-analysis/statistics/data.html) 


\section{F.Ü. Sosyal Bilimler Dergisi 2013-24/1}

Yukarıdaki tabloya bakıldığında, Ürdün'de yaralama suçlarına ilişkin gerçekleşen oranın son derece yüksek olduğu görülmektedir. Bunu ikinci sırada, Türkiye izlemektedir. Türkiye aynı şekilde 2003-2009 yılları arasında yaralama suçlarında en çok artışın gerçekleştiği ülkedir. Tabloda dikkat çeken diğer bir husus da, söz konusu yıllar arasında özellikle Birleşik Arap Emirlikleri ve Lübnan'da bu suç türünde gerçekleşen azalmalardır.

Tablo 8: Bazı Ortadoğu Ülkelerinde İşlenen Motorlu Taşıt Hırsızlığı Suçlarında 100.000 Nüfusta Kişi Başına Düşen Suç Oranı

\begin{tabular}{|l|l|l|l|l|l|l|}
\hline \multirow{2}{*}{ ÜLKELER } & \multicolumn{6}{|c|}{ Motorlu Taşıt Hırsızlı̆̆ } \\
\cline { 2 - 7 } & Yıl & Rakam & Oran & Yıl & Rakam & Oran \\
\hline Mısır & 2003 & 1994 & $\mathbf{2 . 8}$ & 2009 & 3914 & 4.9 \\
\hline Ürdün & 2005 & 3.006 & $\mathbf{5 6 . 3}$ & 2006 & 1438 & 44.4 \\
\hline Kuveyt & 2003 & 6 & $\mathbf{0 . 3}$ & 2009 & 45 & $\mathbf{1 . 7}$ \\
\hline Lübnan & 2005 & 1734 & $\mathbf{4 2 . 8}$ & 2006 & 1971 & 48.1 \\
\hline Umman & 2007 & 179 & $\mathbf{7 . 0}$ & 2008 & 177 & $\mathbf{6 . 7}$ \\
\hline Katar & 2003 & 65 & $\mathbf{9 . 9}$ & 2006 & 131 & $\mathbf{1 3 . 4}$ \\
\hline Suriye & 2003 & 529 & $\mathbf{3 . 0}$ & 2008 & 912 & $\mathbf{4 . 6}$ \\
\hline Türkiye & 2003 & 25.443 & $\mathbf{3 8 . 4}$ & 2008 & 17.988 & $\mathbf{2 5 . 4}$ \\
\hline Birleşik Arap Emir. & 20003 & 677 & $\mathbf{1 9 . 9}$ & 2006 & 606 & $\mathbf{1 3 . 0}$ \\
\hline İran & 2003 & 81.075 & $\mathbf{1 1 9 . 1}$ & 2004 & 94413 & $\mathbf{1 3 7 . 0}$ \\
\hline Bahreyn & 2003 & 725 & $\mathbf{1 1 2 . 0}$ & 2008 & 1094 & $\mathbf{1 0 4 . 0}$ \\
\hline
\end{tabular}

(Kaynak: http://www.unodc.org/unodc/en/data-and-analysis/statistics/data.html)

Motorlu taşıt hırsızlığı yukarıda yer alan Ortadoğu ülkeleri arasında en çok işlenen ülkelerin başında İran, Bahreyn, Lübnan ve Ürdün gelmektedir. Türkiye, diğer suçların aksine bu suç türünde birinci sırada yer almamaktadır. Aynı şekilde 2003 yılına kıyasla 2009 yılında bu suç türünde ciddi bir azalmanın gerçekleştiği gözlemlenmektedir. Özelikle İran, Bahreyn ve Mısır'da bu suç türünde bir artış yaşanmıştır.

Tablo 9: Bazı Ortadoğu Ülkelerinde İşlenen Kaçırma Suçlarında 100.000 Nüfusta Kişi Başına Düşen Suç Oranı

\begin{tabular}{|l|c|c|c|c|c|c|}
\hline \multirow{2}{*}{ ÜLKELER } & \multicolumn{7}{|c|}{ Kaçırma } \\
\cline { 2 - 7 } & Yıl & Rakam & Oran & Yıl & Rakam & Oran \\
\hline Mısır & 2003 & 16 & $\mathbf{0 . 0}$ & 2009 & 70 & $\mathbf{0 . 1}$ \\
\hline Ürdün & 2005 & 28 & $\mathbf{0 . 5}$ & 2006 & 34 & $\mathbf{0 . 6}$ \\
\hline Kuveyt & 2004 & 285 & $\mathbf{1 3 . 0}$ & 2009 & 358 & $\mathbf{1 2 . 8}$ \\
\hline Uübnan & 2005 & 129 & $\mathbf{3 . 2}$ & 2006 & 37 & $\mathbf{0 , 9}$ \\
\hline Katar & 2007 & 13 & $\mathbf{0 . 5}$ & 2008 & 9 & $\mathbf{0 . 3}$ \\
\hline Suriye & 2003 & 7 & $\mathbf{1 . 1}$ & 2004 & 6 & $\mathbf{0 . 8}$ \\
\hline Türkiye & 2003 & 85 & $\mathbf{0 . 5}$ & 2008 & 24 & $\mathbf{0 . 1}$ \\
\hline Birleşik Arap Emir. & 2003 & 7.753 & $\mathbf{1 1 . 7}$ & 2009 & 10.509 & $\mathbf{1 4 . 8}$ \\
\hline Bahreyn & 2003 & 434 & $\mathbf{1 2 . 8}$ & 2006 & 971 & $\mathbf{2 0 . 8}$ \\
\hline Yemen & 2003 & 5 & 0.8 & 2006 & 21 & 2.6 \\
\hline
\end{tabular}

(Kaynak: http://www.unodc.org/unodc/en/data-and-analysis/statistics/data.html) 
Kaçırma suçlarının en çok işlendiği ülkelerin başında Birleşik Arap Emirlikleri, Türkiye ve Kuveyt gelmektedir. Bu ülkelerde aynı zamanda bu suç türündeki artışlar devam etmiştir. Artışların en çok gerçekleştiği ülke ise Birleşik Arap ülkeleri ve Türkiye'dir.

Tablo 10: Bazı Ortadoğu Ülkelerinde İşlenen Adam Öldürme Suçunda 100.000 Nüfusta Kişi Başına Düşen Suç Oranı

\begin{tabular}{|l|c|c|c|c|c|c|}
\hline \multirow{2}{*}{ ÜLKELER } & \multicolumn{6}{|c|}{ Adam Öldürme } \\
\cline { 2 - 7 } & Yıl & Rakam & Oran & Yıl & Rakam & Oran \\
\hline Musır & 2003 & 471 & $\mathbf{0 . 7}$ & 2009 & 992 & $\mathbf{1 . 2}$ \\
\hline Ürdün & 2002 & - & $\mathbf{1 . 2}$ & 2008 & - & $\mathbf{1 . 1}$ \\
\hline Kuveyt & 2005 & 67 & $\mathbf{1 . 3}$ & 2006 & 100 & $\mathbf{1 . 8}$ \\
\hline Lübnan & 2004 & 99 & $\mathbf{4 . 5}$ & 2009 & 59 & 2.2 \\
\hline Umman & 2004 & 123 & $\mathbf{3 . 1}$ & 2010 & 95 & 2.2 \\
\hline Katar & 2002 & 15 & $\mathbf{0 . 7}$ & 2007 & 18 & $\mathbf{0 . 7}$ \\
\hline Suriye & 2003 & 4 & $\mathbf{0 . 6}$ & 2008 & 13 & $\mathbf{0 . 9}$ \\
\hline Türkiye & 2002 & 368 & $\mathbf{2 . 2}$ & 2010 & 463 & $\mathbf{2 . 3}$ \\
\hline Birleşik Arap Emir. & 2003 & 2877 & $\mathbf{4 . 3}$ & 2008 & 2320 & $\mathbf{3 . 3}$ \\
\hline İan & 2003 & 45 & $\mathbf{1 . 3}$ & 2006 & 39 & $\mathbf{0 . 8}$ \\
\hline Suudi Arab. & 2002 & 285 & $\mathbf{1 . 3}$ & 2007 & 265 & $\mathbf{3 . 0}$ \\
\hline Irak & & & & 2008 & 608 & $\mathbf{2 . 0}$ \\
\hline Bahreyn & 2003 & 3 & $\mathbf{0 . 5}$ & 2008 & 6 & $\mathbf{0 . 6}$ \\
\hline Yemen & 2003 & 704 & $\mathbf{3 . 6}$ & 2009 & 990 & $\mathbf{4 . 2}$ \\
\hline
\end{tabular}

(http://www.unodc.org/unodc/en/data-and-analysis/homicide.html)

Adam öldürme suç oranlarına bakıldığında da bazı ülkelerde yıllar bazında artma gerçekleşirken bazı ülkelerde de azalmalar gerçekleşmiştir. Ancak gerçekleşen artma veya azalmalar yıllar bazında nüfusa oranlandığında, çok ciddi düzeyde bir değişimin oluşmadığı görülmektedir.

Yukarda Ortadoğu ülkelerine ilişkin 100.000 nüfusta kişi başına düşen suç oranları genel olarak değerlendirildiğinde bazı suç türlerinde bir artışın yaşandığını söylemek mümkündür. Günümüzde genelde gelişmiş ülkelere nispeten gelişmekte olan ülkelerde suç oranlarının daha çok artması beklenmektedir. Gelişmekte olan ülkelerdeki suç artışları, söz konusu toplumların modernleşme süreçleri ve dinamikleri ile açıklanabilir. Gelişmekte olan ülkelerde artan suçluluğun nedenleri arasında özellikle; aile kurumunda meydana gelen değişmeler, giderek artan bireyselcilik, yerleşimsel hareketliliğin yol açtı̆̆ sosyal organizasyonsuzluk, sosyal sermayenin ve enformel denetimin zayıflaması, ekonomik gelişmeler ve bu alandaki gelişmelerin yarattığı sorunlar (işsizlik, yoksulluk, göreli yoksulluk) gibi faktörlerin öne çıtığı görülmektedir. Junger-Tas (1996), düşük suç oranlarına sahip olan ülkelerde suç oranlarının artmasını üç nedenle açıklamaktadır.

1. Nüfus hareketliliği ve şehir merkezlerindeki azınlıkların ve sığınmacıların hareketliliği ve yerleşimi. Bu alanlarda sürtüşme ve çatışmaların ortaya çıkma ihtimali söz konusudur.

2. Homojen bir nüfustan heterojen bir nüfusa doğru gerçekleşen değişim: Bu süreçte farklı değerler sistemi ortaya çıkmaktadır.

3. Sosyo-ekonomik koşullarda meydana gelen değişim: Ekonomik bütünleşmeyi engelleyen ve alt sınıfın gelişimini sağlayan türden bir ekonomik gelişme. 


\section{F.Ü. Sosyal Bilimler Dergisi 2013-24/1}

Modernleşme süreci ile birlikte Ortadoğu veya İslami olarak nitelendirilen ülkelerde aşağıda belirtilen bazı gelişmelerin baş göstertmesi, suç oranlarının artışında etkili unsurlar olarak belirtilebilir.

* Aile yapilarının bozulması,

* Sosyo-kültürel değerlerin zayıflaması,

* Bireyselliğin gelişimi,

* Nüfusun heterojenleşmesi,

* Kadının konumundaki değişmeler,

* Sosyal denetimin zayiflamas1,

* Kitle iletişim araçlarının yaygınlaşması ve giderek etkileyici gücünün artması,

* Göreli yoksulluk, işsizlik ve ekonomik sorunların baş göstermesi gibi gelişmelerin ortaya çıkması muhtemeldir. Bu gelişmelerin de suç oranları üzerinde tetikleyici bir işlevi yerine getireceğini söylemek mümkündür.

\section{SONUÇ}

Ortadoğu ülkelerinde işlenen suç oranları gelişmiş olan ülkelere kıyasla-cinayet suçları hariçson derece düşüktür. Diğer bir ifade ile gelişmiş ülkelerde işlenen; yaralama, cinsel suçlar, soygun, hırsızlık, uyuşturucu ile ilintili suçlar, adam kaçırma ve taşıt suçları Ortadoğu ülkelerinde işlenen suç oranlarından oldukça yüksektir. Ortadoğu veya İslam ülkelerinde suç oranlarının düşük olmasının önde gelen nedeni olarak bu ülkelerde geleneksel yapının ağırlıklı olarak hakim olması ve aynı şekilde bununla ilintili olarak enformel kurumsal denetim unsurlarının güçlülüğü belirtilebilir. Bunun yanında suçlara öngörülen cezaların sertliği de suç oranlarının düşük gerçekleşmesinin önemli bir nedenini oluşturmaktadır.

Özellikle Ortadoğu coğrafyasında yer alan ülkelerde dinsel kurumlar toplum üzerinde ciddi bir denetim unsurunu oluşturmaktadır. Ayrıca bu ülkelerde toplumsal değişmenin son derece yavaş ve sınırlı olması da, bu ülkelerde suç oranlarının gelişmiş ülkelere kıyasla çok küçük düzeyde seyretmesinin önde gelen nedenini oluşturmaktadır. Ancak bazı ülkelerde 2003-2009 yıllarını kapsayan dönemler arasında belirli suç türlerinde bazı artışların gerçekleştiği gözlemlenmektedir. $\mathrm{Bu}$ artışlar da, son dönemlerde kısmen de olsa Ortadoğu coğrafyasının küreselleşme dalgasından etkilenerek yavaş da olsa bir değişim gerçeği ile karşı karşıya gelmesi ile açıklanabilir. Diğer bir ifade ile son dönemlerde, küreselleşme ve modernleşme ile süreci ile birlikte Ortadoğu ülkelerinde gerçekleşen görece sosyo-kültürel, demografik ve ekonomik değişim çabaları artan suç oranlarının nedenleri olarak ele alınabilir. Bu çerçevede bazı Ortadoğu ülkelerinde suç oranlarının artışı, söz konusu ülkelerde kısmi toplumsal değişme ve modernleşme dinamiklerinin gelişmesi ile doğrudan ilintili olarak görülebilir.

Suç oranlarının en çok arttığı ülkelerin başında da Türkiye gelmektedir. Türkiye'de işlenen suç oranlarının diğer Ortadoğu ülkelerine kıyasla, çok fazla gerçekleşmesi ve yıllar bazında gerçekleşen artışların nedeni, diğer ülkelere kıyasla Türkiye'nin modernleşme geçmişinin çok daha uzun ve modernleşme dinamiklerinin daha güçlü olması ile açıklanabilir. Diğer bir ifade ile çoğu Ortadoğu ülkelerinde modernleşme veya değişme dinamikleri Türkiye'ye kıyasla son derece cılız kalmaktadır. Özellikle Türkiye'de 90'l1 y1llardan sonra benimsenen ve 2000'li yıllardan sonra hızlanan liberal politikalar, Avrupa birliği süreci ve küresel dünya ile iletişimin artmış olması, radikal ve köklü değişimleri beraberinde getirmiştir. Özellikle bu değişme sürecinde ortaya çıkan sorunlar, geleneksel değer ve kurumların zayıflamasında etkili olduğu söylenebilir. Türkiye' den sonra suç oranlarında artış eğilimi sergileyen ülkeler içerisinde dikkat çeken ülkelerin başında özellikle Kuveyt, Ürdün, Amman ve Birleşik Arap Emirlikleri gelmektedir.

Modernleşme süreci ile birlikte gelişmekte olan ülkelerde (Ortadoğu veya İslami olarak nitelendirilen ülkeler de dahil); aile yapılarının bozulması, sosyo-kültürel değerlerin zayıflaması, bireyselciliğin gelişimi, sosyal denetimin zayıflaması, göreli yoksulluk ve ekonomik sorunların baş göstermesi gibi gelişmeler suç oranlarının artmasında etkili olan unsurlar olarak öne çıkmaktadır. 
Modernleşme süreci ile birlikte sosyal kontrol mekanizmaları zayıflamakta ve normatif kurallar belirsiz olmaya başlamaktadır. Bu çerçevede ülkemizde ve Ortadoğu ülkelerinde artan suçluluk oran1, modernleşme perspektifinden analiz edilebilir.

Sonuç olarak; gelişmekte olan veya Orta Doğu Ülkelerinde suç oranlarındaki artışların nedenleri olarak şu unsurlar belirtilebilir:

* Göç ve kentleşmenin yarattı̆̆ı sosyal organizasyonsuzluk,

* Nüfusun heterojenleşmesi,

* Değerler alanındaki değişim, sosyal sermayenin azalması

* Geleneksel veya enformel denetim unsurlarının zayıflaması

* Aile kurumunda meydan gelen değişim

* Ekonomik sorunlar (gelir eşitsizliği, yoksulluk, düşük gelir, alt sosyal sınıf) veya iş istikrarlığının yıkılması

* Bireyselciliğin gelişimi ve kişisel çıkar arayışları

* Bireylerin ben merkezli, egoist bir motivasyonla hareket etmeye başlamaları,

* Kadının sosyal konumundaki dönüşümler,

* Suç işleme firsatlarında meydana gelen artışlar,

* Artan ekonomik motivasyonlar,

* Kitle iletişim araçlarının giderek daha etkili olmaya başlaması. Özellikle internet kullanımının yaygınlığı da suç oranlarının artışında etkili olabilmektedir.

Toplumsal ve siyasal bir hareketlenme içerisinde bulunan Ortadoğu coğrafyasında gelecek dönemlerde modernleşme dinamiklerinin gelişmesi ve güçlenmesi ile birlikte suç oranlarında belirli bir oranda artışların gerçekleşeceği ve bazı suçların niteliğinde de belirli değişmelerin yaşanacağını şimdiden tahmin etmek güç değildir.

\section{KAYNAKÇA}

Arı, T. (2005), Geçmişten Günümüze Ortadoğu: Siyaset, Savaş ve Diplomasi, İstanbul: Alfa Yay.

Barak, G. (1998), Integrating Criminologies. Boston: Allyn and Bacon

Barlow, H.D. (1993). Introduction to Criminology. New York: Harper Collins College Publishers.

Braithwaite, J. (1989), Crime, Shame and Reintegration, Cambridge: Cambridge University Press.

Fukayama, F.(1999). Büyük Bozulma: İnsanın Doğası ve Toplumsal Düzenin Yeniden Oluşması, ( Çev: Zeynep Avc1, Aslı T. Aydemir). İstanbul: Sabah Kitapları Yay.

Haddad, G. K. and Moghadam, H. M. (2011), "The Socioeconomic and Demographic Determinants of Crime in Iran (a Regional Panel Study)”, Eur J. Law Econ, 32: 99-114

Harrendorf, S., Heiskanen, M. and Malby, S. (eds), (2010), Internatioanl Statistics on Crime and Criminal Justice, United Nations Office on Drugs and Crime (UNODC), Helsinki: Heuni Pub. İnternet erişim: http://www.heuni.fi/ Etusivu/Publications/HEUNIreports/

Junger-Tas, J. (1996), "Youth and Violence in Europe", Studies on Crime and Crime Prevention, 5: 31-

Serajzadeh, S. H. (2001), "Islam and Crime: The Moral Community of Muslims", Journal of Arabic and Islamic Studies, 4/4 (2001-2): 111-31

United Nations Office on Drugs and Crime (UNODC) (2011), Global Study on Homicide: Trends, Contexts, Data

Zhang, S.X. (1995), Measuring Shaming in an Ethnic Context. British Journal of Criminology. 35(2): 248-262.

(http://www.unodc.org/unodc/en/data-and-analysis/homicide.html)

http://www.unodc.org/unode/en/data-and-analysis/statistics/data.html 
